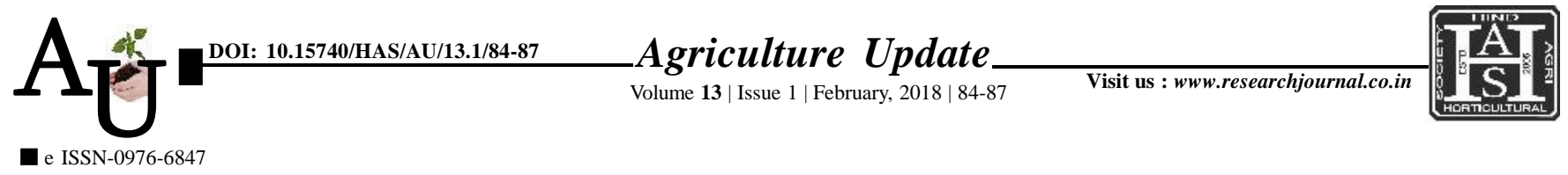

\title{
Research Aвticle: An impact assessment study of utilization of MGNREGA income by daily waged women workers
}

\section{Priyanshu Tripathi and Nikita Wadhawan}

Article Chronicle:

Received :

01.12.2017;

Revised :

03.01.2018;

Accepted :

19.01.2018

\section{KeY WoRdS:}

MGNREGA, Women

beneficiaries, Income

Author for correspondence :

Priyanshu Tripathi

Department of Foods and Nutrition, College of Home Science,

Maharana Pratap

University of Agriculture and Technology, Udaipur (Rajasthan) India

Email:tripathipriyu89@ gmail.com

See end of the article for authors' affiliations
SUMMARY : Mahatma Gandhi National Rural Employment Guarantee Act (MGNREGA) is considered as a "Silver Bullet" for eradicating rural poverty and unemployment, by way of generating demand for productive labour force in villages. It provides an alternative source of livelihood. It has been considered as the largest anti-poverty programme in the world. The MGNREGA and food security are significantly interlinked and the act gives a necessary push to the purchasing power. As women are essential parts of a society. Provision of employment opportunities and income to rural women is one way to improve their nutrition, health, education and social status. The present study was conducted in Baran district of Rajasthan for assessing utilization of MGNREGA income by daily waged women worker. It was reported by majority of the respondents $(93.6 \%)$ reported that participation in MGNREGA increased their family income. The average increase income of most of the respondents $(43.20 \%)$ before and after joining programme was between in the range of Rs. 500-2500/-. The mean gain income was Rs. 1430.57/ - which was significantly higher. MGNREGA has substantially improved the purchasing power leading to provision of quality food from hand to mouth. Economic participation helped the respondents in increasing their resources, food consumption, clothing and housing. It also helped them to reduce the debt.

How to cite this article : Tripathi, Priyanshu and Wadhawan, Nikita (2018). An impact assessment study of utilization of MGNREGA income by daily waged women workers. Agric. Update, 13(1): 84-87; DOI : 10.15740/ HAS/AU/13.1/84-87. 